\title{
Pola Kuman dan Uji Kepekaan Antibiotik pada Pasien Unit Perawatan Intensif Anak di Rumah Sakit Umum Daerah Koja Jakarta
}

Riza Mansyoer, Ivan R. Widjaja

Unit Perawatan Intensif Anak RSUD Koja Jakarta

Latar belakang. Pasien di unit perawatan intensif (UPI) anak (pediatric intensive care unit/PICU) merupakan pasien dengan penyakit kritis sehingga sebagian besar pasien menggunakan antibiotik. Profil resistensi bakteri akan membantu untuk pemilihan terapi empirik yang akan digunakan pada suatu unit.

Tujuan. Untuk mendapatkan profil bakteri di PICU RSUD Koja berdasarkan hasil kultur,

Metode. Hasil kultur yang dilakukan pada seluruh pasien yang masuk ke PICU pada periode Mei 2015 - April 2016 pada hari kerja pertama dikumpulkan dari departemen patologi klinik RSUD Koja

Hasil. Didapatkan 486 hasil kultur, 410 di antaranya tidak menunjukkan pertumbuhan kuman. Hasil positif terdapat pada 64 bakteri Gram-positif dan 12 Gram-negatif. Bakteri Gram positif terbanyak ditemukan adalah Staphylococcus hominis (19), Staphylococcus epidermidis (18), Staphylococcus haemolyticus (13), dan Staphylococcus aureus (9). Sementara itu, bakteri Gram negatif terbanyak ditemukan adalah Salmomella typhi (6) dan Acinetobacter baumanii (2). Pada kelompok bakteri Gram positif, antibiotik yang paling sensitif adalah vancomisin $(95,2 \%)$, gentamisin $(68,3 \%)$, cotrimoxazole $(44,4 \%)$, cefotaxime $(31,7 \%)$, dan ceftriaxone $(31,7 \%)$. Pada kelompok bakteri Gram negatif, antibiotik yang paling sensitif adalah meropenem $(84,6 \%)$, cotrimoxazole $(84,6 \%)$, amikasin $(61,5 \%)$, gentamisin $(53,8 \%)$, and cefepime $(46,2 \%)$.

Kesimpulan. Vankomisin merupakan antibiotik yang paling poten untuk digunakan. Cefotaxime dan gentamicin kami pilih untuk digunakan sebagai antibiotik empirik di unit kami, dengan meropenem sebagai lini berikutnya. Vankomisin kami gunakan hanya pada kasus khusus. Sari Pediatri 2017;19(2):103-7

Kata kunci: PICU, antibiotik, kultur, Kepekaan antibiotik

\section{Koja General Hospital Pediatric Intensive Care Unit Bacteriological Profile}

Riza Mansyoer, Ivan R. Widjaja

Background. Patients in pediatric intensive care unit (PICU) are critically ill patients therefore antibiotics was used to most of them. Bacteriological profile will help clinician in choosing antibiotics to treat infection empirically.

Objective. This study was meant to analyze bacteriological profile in PICU Koja general hospital in May 2015 - April 2016.

Methods. Blood culture results withdrawn when patients came PICU at the first time was obtained from the database.

Results. We managed to obtain 486 blood culture results, 410 among them were sterile. Positive results showed 64 Gram-positive microorganisms and 12 Gram-negative microorganisms. The most common microorganisms found in Gram-positive group were Staphylococcus hominis(19), Staphylococcus epidermidis (18), Staphylococcus haemolyticus (13), and Staphylococcus aureus (9). While in Gram negative group were Salmomella typhi (6) and Acinetobacter baumanii (2). For Gram-positive microorganisms, the most susceptible antibiotics were vancomycin(95,2\%), gentamycin $(68,3 \%)$, cotrimoxazole $(44,4 \%)$, cefotaxime $(31,7 \%)$, and ceftriaxone $(31,7 \%)$. For Gram-negative microorganisms, the most susceptible antibiotics were meropenem $(84,6 \%)$, cotrimoxazole $(84,6 \%)$, amikacin $(61,5 \%)$, gentamycin $(53,8 \%)$, and cefepime $(46,2 \%)$.

Conclusion. Vancomycin was the most susceptible antibiotics. Cefotaxime and gentamicin were chosen for empiric treatment, keeping meropenem and vancomycin behind. Sari Pediatri 2017;19(2):103-7

Keywords: PICU, antibiotics, culture, microbial resistance

Alamat korespondensi: Dr. Riza Mansyur, SpA; Dr. Ivan R. Widjaja, SpA. Unit Perawatan Intensif Anak RSUD Koja Jakarta Email: drrizamansyoer@rocketmail. com; ivanr23@yahoo.com 
$\mathrm{P}$ asien di ruang perawatan intensif anak adalah anak dengan penyakit kritis sehingga penggunaan antibiotik empirik dilakukan hampir pada seluruh pasien yang dirawat. Pasien yang dirawat di unit perawatan intensif (UPI) anak sebagian besar telah mengalami infeksi saat masuk atau memiliki risiko yang tinggi untuk mengalami infeksi. ${ }^{1} 3$ months surveillance of antibiotic use on PICU (phase I Salah satu UPI anak di India menggunakan antibiotik pada seluruh pasien yang masuk. Pada unit tersebut antibiotik empirik diberikan pada $42 \%$ kasus sedangkan hanya 15 persen yang diberikan antibiotik terapeutik. ${ }^{2}$

Pemilihan terapi empirik seyogyanya dilakukan berdasarkan pola kuman dan resistensi kuman pada masing-masing unit. Sebagian besar pola kuman dan resistensi yang dilaporkan di berbagai jurnal berasal dari unit perawatan intensif neonatal. Tujuan penelitian ini untuk mendapatkan pola kuman dan resistensi di UPI anak RSUD Koja.

\section{Metode}

Studi deskriptif berdasarkan data kultur darah saat pasien masuk UPI anak RSUD koja selama 1 tahun, periode 1 Mei 2015 hingga 30 April 2016. Kultur darah dilakukan pada seluruh pasien UPI anak RSUD Koja saat mereka masuk, tanpa memperhatikan diagnosis pasien. Data diambil dari unit patologi klinik RSUD Koja. Spesimen kultur darah di RSUD Koja diambil hanya pada jam kerja, dilakukan dengan prosedur yang steril oleh laboran. Pasien yang masuk di luar jam kerja akan menjalani pemeriksaan kultur darah di jam kerja berikutnya. Data yang digunakan adalah data kultur darah yang pertama kali diambil saat pasien masuk UPI anak.

\section{Hasil}

Selama periode penelitian didapatkan 486 data hasil kultur darah yang dilakukan di UPI anak RSUD Koja. Empat ratus sepuluh $(84,4 \%)$ di antaranya tidak menunjukkan adanya pertumbuhan kuman dalam darah. Data lengkap kuman yang tumbuh tertera pada Tabel 1 .

Pola sensitivitas kuman Gram positif terhadap antibiotik tertera pada Tabel 2, sedangkan Gram negatif tertera pada Tabel 3. Berdasarkan pola ini dapat dilihat bahwa kuman gram positif dan negatif masih sensitif terhadap Gentamicin, Cefotaxime, dan Ko-trimoxazole.

Pada kuman MRSE, antibiotik yang masih sensitif untuk digunakan adalah Gentamicin, Amikasin, Ciprofloxacin, Levofloxacin, dan Vancomycin. Karena adanya kekhawatiran dalam penggunaan quinolone pada anak, antibiotik yang masih dapat digunakan untuk mengatasi kuman MRSE adalah Gentamicin dan Amikasin dengan Vancomycin sebagai cadangan.

Tabel 1. Hasil kultur darah yang menunjukkan adanya pertumbuhan kuman

\begin{tabular}{llc}
\hline Kelompok & Mikroorganisme & Jumlah isolat \\
\hline Gram positif & Staphylococcus hominis & 19 \\
& Staphylococcus epidermidis & 18 \\
& Staphylococcus haemolyticus & 13 \\
Staphylococcus aureus & 9 \\
Micrococcus luteus & 2 \\
Staphylococcus viridans & 1 \\
Micrococcus rosea & 1 \\
Gram negatif & Salmonella typhi & 6 \\
& Acinetobacter Baumanii & 2 \\
& Achromobacter xylosoxidans & 1 \\
& Acinetobacter lwoffi & 1 \\
& Enterobacter cloacae & 1 \\
& Escherichia coli & 1 \\
& Klebsiella pneumonia & 1 \\
\hline
\end{tabular}


Riza Mansyoer dkk: Pola kuman dan uji kepekaan antibiotik pada pasien unit perawatan intensif anak di RSUD Koja, Jakarta

Tabel 2. Pola sensitivitas kuman Gram positif ( $\mathrm{n}(\%))$

\begin{tabular}{lccccccc}
\hline Antibiotik & S. hominis & S. epidermidis & S. haemolyticus & S. aureus & M. luteus & S. viridans & M. rosea \\
\hline Amoxicillin & $5(26,3)$ & $4(22,2)$ & $0(0)$ & $2(22,2)$ & $2(100)$ & $1(100)$ & $1(100)$ \\
Oxacillin & $8(42,1)$ & $2(11.1)$ & $0(0)$ & $4(44.4)$ & $2(100)$ & $0(0)$ & $0(0)$ \\
Amoxicillin Clavulanat & $8(42,1)$ & $4(22,2)$ & $0(0)$ & $6(66,7)$ & $2(100)$ & $1(100)$ & $0(0)$ \\
Ampicillin sulbactam & $7(36,8)$ & $4(22,2)$ & $0(0)$ & $3(33,3)$ & $2(100)$ & $1(100)$ & $0(0)$ \\
Cefuroxime & $7(36,8)$ & $4(22,2)$ & $0(0)$ & $3(33,3)$ & $2(100)$ & $1(100)$ & $1(100)$ \\
Cefaclor & $8(42,1)$ & $5(27,8)$ & $0(0)$ & $6(66,7)$ & $2(100)$ & $1(100)$ & $0(0)$ \\
Cefoperazone & $8(42,1)$ & $3(16,7)$ & $0(0)$ & $5(55,6)$ & $2(100)$ & $1(100)$ & $0(0)$ \\
Ceftazidime & $8(42,1)$ & $2(11,1)$ & $0(0)$ & $4(44,4)$ & $2(100)$ & $1(100)$ & $0(0)$ \\
Ceftriaxone & $8(42,1)$ & $2(11,1)$ & $0(0)$ & $2(22,2)$ & $2(100)$ & $1(100)$ & $0(0)$ \\
Cefotaxime & $8(42,1)$ & $3(16,7)$ & $0(0)$ & $4(44,4)$ & $2(100)$ & $1(100)$ & $0(0)$ \\
Ceftizoxime & $8(42,1)$ & $4(22,2)$ & $0(0)$ & $5(55,6)$ & $2(100)$ & $1(100)$ & $0(0)$ \\
Cefepime & $8(42,1)$ & $4(22,2)$ & $0(0)$ & $5(55,6)$ & $2(100)$ & $1(100)$ & $0(0)$ \\
Cefoxitin & $8(42,1)$ & $4(22,2)$ & $0(0)$ & $6(66,7)$ & $2(100)$ & $1(100)$ & $0(0)$ \\
Meropenem & $8(42,1)$ & $4(22,2)$ & $0(0)$ & $5(55,6)$ & $2(100)$ & $1(100)$ & $0(0)$ \\
Gentamicin & $8(42,1)$ & $3(16,7)$ & $0(0)$ & $4(44,4)$ & $2(100)$ & $1(100)$ & $1(100)$ \\
Amikasin & $19(100)$ & $11(61,1)$ & $2(15,4)$ & $8(88,9)$ & $2(100)$ & $1(100)$ & $0(0)$ \\
Ciprofloxacin & $1(5,3)$ & $9(50)$ & $0(0)$ & $0(0)$ & $0(0)$ & $1(100)$ & $0(0)$ \\
Levofloxacin & $17(89,5)$ & $11(61,1)$ & $2(15,4)$ & $8(88,9)$ & $2(100)$ & $1(100)$ & $1(100)$ \\
Ko-trimoxazole & $17(89,5)$ & $11(61,1)$ & $2(15,4)$ & $8(88,9)$ & $2(100)$ & $1(100)$ & $1(100)$ \\
Erythromycin & $11(57,9)$ & $8(44,4)$ & $5(38,5)$ & $1(11,1)$ & $2(100)$ & $1(100)$ & $0(0)$ \\
Vancomycin & $8(42,1)$ & $6(33,3)$ & $0(0)$ & $3(33,3)$ & $2(100)$ & $1(100)$ & $0(0)$ \\
Chloramphenicol & $19(100)$ & $17(94,4)$ & $12(92,3)$ & $8(88,9)$ & $2(100)$ & $1(100)$ & $1(100)$ \\
Fosfomycin & $9(47,4)$ & $5(27,8)$ & $0(0)$ & $2(22,2)$ & $2(100)$ & $1(100)$ & $1(100)$ \\
& $9(47,4)$ & $5(27,8)$ & $0(0)$ & $6(66,7)$ & $2(100)$ & $1(100)$ & $0(0)$ \\
\hline
\end{tabular}

Tabel 3. Pola sensitivitas kuman Gram negatif $(\mathrm{n}(\%))$

\begin{tabular}{lcc}
\hline Antibiotik & S. typhi & A. baumanii \\
\hline Amoxicillin & $5(83,3)$ & $0(0)$ \\
Amoxicillin Clavulanat & $3(50)$ & $0(0)$ \\
Ampicillin sulbactam & $5(83,3)$ & $0(0)$ \\
Cefuroxime & $2(33,3)$ & $0(0)$ \\
Cefaclor & $2(33,3)$ & $0(0)$ \\
Cefoperazone & $2(33,3)$ & $0(0)$ \\
Ceftazidime & $4(66,7)$ & $0(0)$ \\
Ceftriaxone & $4(66,7)$ & $0(0)$ \\
Cefotaxime & $3(50)$ & $0(0)$ \\
Ceftizoxime & $3(50)$ & $0(0)$ \\
Cefepime & $4(66,7)$ & $0(0)$ \\
Meropenem & $5(83,3)$ & $1(50)$ \\
Gentamicin & $2(33,3)$ & $1(50)$ \\
Amikasin & $2(33,3)$ & $2(100)$ \\
Ciprofloxacin & $5(83,3)$ & $1(50)$ \\
Levofloxacin & $5(83,3)$ & $0(0)$ \\
Ko-trimoxazole & $5(83,3)$ & $2(100)$ \\
Chloramphenicol & $3(50)$ & $0(0)$ \\
Fosfomycin & $4(66,7)$ & $0(0)$ \\
\hline
\end{tabular}


Tabel 4. Pola sensitivitas pada 10 kuman MRSE yang ditemukan $(\mathrm{n}(\%))$

\begin{tabular}{lc}
\hline Antibiotik & Sensitivitas \\
\hline Penicillin G & $5(50)$ \\
Amoxicillin & $0(0)$ \\
Oxacillin & $0(0)$ \\
Amoxicillin Clavulanat & $0(0)$ \\
Ampicillin sulbactam & $0(0)$ \\
Cefuroxime & $1(10)$ \\
Cefaclor & $0(0)$ \\
Cefoperazone & $0(0)$ \\
Ceftazidime & $0(0)$ \\
Ceftriaxone & $0(0)$ \\
Cefotaxime & $0(0)$ \\
Ceftizoxime & $0(0)$ \\
Cefepime & $0(0)$ \\
Meropenem & $0(0)$ \\
Gentamicin & $6(60)$ \\
Amikasin & $5(50)$ \\
Ciprofloxacin & $5(50)$ \\
Levofloxacin & $5(50)$ \\
Ko-trimoxazole & $3(30)$ \\
Chloramphenicol & $1(10)$ \\
Fosfomycin & $3(30)$ \\
Vancomycin & $9(90)$ \\
\hline
\end{tabular}

\section{Pembahasan}

Pada penelitian ini kultur darah positif adalah 15,6 $\%$, lebih rendah dibandingkan penelitian Wahyudi $\mathrm{dkk}^{3}$ di Palembang, yaitu sebesar 75,4 \%. Hasil yang rendah ini dapat disebabkan oleh beberapa faktor, seperti waktu pengambilan darah yang tidak tepat, volume darah yang tidak adekuat, dan metode kultur yang digunakan. ${ }^{4}$ Pengambilan darah di unit perawatan intensif anak sangat sulit dilakukan sebelum antibiotik mengingat pada kasus yang berat antibiotik telah diberikan di bangsal perawatan. Selain itu, pengerjaan kultur darah yang hanya dilakukan pada jam kerja membuat pengambilan kultur darah kadang baru bisa dilakukan setelah antibiotik kedua (jika diganti atau ditambah) diberikan.

Kuman yang paling sering ditemukan di unit kami adalah Staphylococcus hominis yang merupakan bakteri komensal di kulit manusia dan menghasilkan zat yang berperan pada bau badan. Bakteri ini dapat mengakibatkan infeksi pada pasien dengan sistem imun yang lemah. ${ }^{5}$ Cara pengambilan yang tidak tepat yang mengakibatkan tercemarnya spesimen kultur dengan kuman komensal kulit dapat menjadi alasan banyak ditemukannya bakteri ini di unit kami.

Selain Staphylosoccus hominis, Staphylococcus epidermidis, Staphylococcus haemolyticus, dan Staphylococcus aureus juga menempati urutan teratas bakteri yang ditemukan di unit kami. Keempat spesies Staphyloscoccus ini merupakan kuman komensal kulit infeksi nosokomial dan akan sangat mudah terjadi, apalagi ketika kuman ini menjadi patogen. Walaupun kuman ini ditemukan pada kultur darah, sebaiknya tidak serta merta dianggap sebagai kontaminan. ${ }^{6}$

Sepuluh dari 18 Staphylococcus epidermidis merupakan methicillin resistant Staphylococcus epidermidis (MRSE) dan 1 dari 8 Staphylococcus aureus yang ditemukan merupakan methicillin resistant Staphylococcus aureus (MRSA). Studi yang dilakukan selama 1 tahun di Mymensingh menunjukkan 32 kuman Staphylococcus epidermidis dengan $18 \mathrm{di}$ antaranya merupakan MRSE yang sensitif terhadap rifampisin dan INH dan $100 \%$ resisten terhadap Penicillin, Amoxcycillin, oxacillin, dan cloxacillin. ${ }^{7}$ Pada penelitian ini, 9 dari 10 MRSE yang ditemukan sensitif terhadap vankomisin dengan resistensi.

Berdasarkan pola sensitivitas kuman yang kami temukan, antibiotik empirik yang kami pilih untuk digunakan adalah kombinasi cefotaxim dan gentamicin. Sementara penggunaan vankomisin kami batasi hanya pada kasus tertentu. Hal tersebut cukup berbeda dengan penelitian Abbas $\mathrm{dkk}^{2}$ di Pakistan yang menunjukkan bahwa unit perawatan intensif anak di sana paling banyak menggunakan meropenem, vankomisin, dan ceftriaxone sebagai antibiotik empirik. Walaupun Ko-Trimoxazole menunjukkan efektivitas yang cukup baik, tetapi mengingat sediaan antibiotik merupakan sediaan oral sehingga sukar digunakan pada kasus yang dirawat di unit kami.

Penggunaan antibiotik yang rasional dengan memperhatikan pola kuman yang didapatkan dari hasil kultur perlu dilakukan untuk mencegah terjadinya resistensi antibiotik. Pada UPI anak RSUD koja antibiotik yang kami jadikan pilihan adalah Cefotaxime dan Gentamicin untuk lini pertama. 
Riza Mansyoer dkk: Pola kuman dan uji kepekaan antibiotik pada pasien unit perawatan intensif anak di RSUD Koja, Jakarta

\section{Daftar pustaka}

1. Stocker M, Ferrao E, Banya W, Cheong J, Macrae D, Furck A. Antibiotic surveillance on a paediatric intensive care unit: easy attainable strategy at low costs and resources. BMC Pediatr 2012;12:196.

2. Abbas Q, Ul Haq A, Kumar R, Ali S, Hussain K, Shakoor S. Evaluation of antibiotic use in Pediatric Intensive Care Unit of a developing country. Indian J Crit Care Med 2016;20:291-4

3. Wahyudhi A, Triratna S. Pola Kuman dan Uji Kepekaan Antibiotik pada Pasien Unit Perawatan Intensif Anak RSMH Palembang. Sari Pediatri 2010;12:1-5.

4. Oyong N, Anggraini D, Karina K. Pola Resistensi Bakteri
Penyebab Sepsis Neonatorum di Instalasi Perawatan Neonatus RSUD Arifin Achmad Riau. Sari Pediatri 2016;17:435-40.

5. Mendoza-Olazarán S, Morfin-Otero R, Rodríguez-Noriega E, dkk. Microbiological and Molecular Characterization of Staphylococcus hominis Isolates from Blood. PLoS One 2013;8:e61161.

6. Haque N, Bari MS, Haque N, dkk. Methicillin resistant Staphylococcus epidermidis. Mymensingh Med J 2011;20:326-31.

7. Haque N, Bari MS, Bilkis L, dkk. Prevalence and antimicrobial resistance of methicillin resistant Staphylococcus epidermidis isolated at Mymensingh Medical College Hospital. Mymensingh Med J 2010;19:163-9. 